\title{
NOTE ON THE DISCRETE OSTROWSKI-GRÜSS TYPE INEQUALITY
}

\section{Yu MiaO}

Abstract. In the present note, we establish several new discrete Ostrowski-Grüss type inequalities which extend some known results.

Mathematics subject classification (2000): 26D15.

Keywords and phrases: Inequality, Ostrowski-Grüss type, random variable.

\section{REFERENCES}

[1] X. L. Cheng And J. Sun, A note on the perturbed trapezoid inequality, JIPAM. J. Inequal. Pure Appl. Math. 3(2), Article 29, (2002).

[2] S. S. DRAGOMIR, A Grüss type discrete inequality in inner product spaces and applications, J. Math. Anal. Appl., 250(2) 494-511, (2000).

[3] S. S. DRAGOMIR, The discrete version of Ostrowski's inequality in normed linear spaces, J. Inequal. Pure and Appl. Math. 3(1) Art. 2, (2002).

[4] S. S. Dragomir, A companion of the Grïss inequality and applications, Appl. Math. Lett. 17 429435 (2004).

[5] S. S. DRAGOMIR AND S. WANG, An inequality of Ostrowski-Grüss' type and its applications to the estimation of error bounds for some special means and for home numerical quadrature rules, Computers Math. Applic. 33 (11), 15-20 (1997).

[6] N. Elezović, Lu. Marangunić AND J. PeČARIć, Some improvements of Grüss type inequality, J. Math. Inequal. 1(3), 425-436 (2007).

[7] Z. LiU, A sharp integral inequality of Ostrowski-Grüss type, Soochow J. Math. 32(2), 223-231 (2006).

[8] M. MATIĆ, J. PEČARIĆ AND N. UJEVIĆ, Improvement and further generalization of inequalities of Ostrowski-Grüss type, Computers Math. Applic. 39 (3/4), 161-175 (2000).

[9] A. M. MERCER, An improvement of the Grüss inequality, JIPAM. J. Inequal. Pure Appl. Math. 6(4), Article 93 (2005).

[10] D. S. Mitrinović AND J. PeČARIĆ, Monotone functions and their inequalities, Naučna Knjiga, Belgrade, 1990.

[11] D. S. Mitrinović, J. PeČArić And A. M. Fink, Classical and New Inequalities in Analysis, Kluwer Academic Publishers, Dordrecht, (1993).

[12] A. Ostrows KI, Über die Absolutabweichung einer differenzierbaren Funktion von ihrem Integralmittelwert, Comment. Math. Helv. 10, 226-227 (1938) (German).

[13] B. G. Pachpatte, New discrete Ostrowski-Grüss like inequalities, Facta Univ. Ser. Math. Inform. 22 (1), 15-20 (2007). 